\title{
EMPIRICAL ANALYSIS OF INCOME INEQUALITIES AND WELFARE AMONG FARMERS IN SOUTH EASTERN NIGERIA
}

\author{
N .M. Agwu ${ }^{1}$ and C.O.Orji ${ }^{1}$
}

\begin{abstract}
The study analysed income inequalities and welfare of farmers in South Eastern Nigeria, using Abia State where the occupation of majority is farming. Specifically, the study accessed the income inequalities of the farmers; determine the factors that influence welfare among the farmers in the study area; and made recommendations based on the findings. Multi-stage sampling technique was adopted for this study. First, two Local Government Areas were selected from each of the three agricultural zones. From these Local Government Areas, three communities were chosen. Finally, a random selection of twenty farmers was selected each from the three communities, bringing total of one hundred and eighty (180) farmers/respondents. Primary source of data was used for the study. This was actualized with questionnaire administered to the already selected respondents. The study employed Gini-coefficient and multiple regression in the analysis of the data collected. The Gini coefficient value was 0.67, showing that there was high income inequality in the study area. The regression result that determined the factors influencing farmer's welfare showed that marital status, farm size, access to credit, value of access, cost of labour, farming experience and household size were major determinants of farmers'welfare. The study recommended that government policies targeted at farmers should be strengthened, cost saving technologies should be introduced and farmer educated to adopt such measures, amongst others.
\end{abstract}

Key words: Income, inequalities, welfare of farmers, south eastern Nigeria.

\section{INTRODUCTION}

Income distribution pattern over the years has been a major concern in the determination of the level of economic growth and development of any country.

Specifically, the 1990s witnessed resurgence in theoretical and empirical attention by economists to the distribution of income and wealth (Atkinson and Bourguignon, 2000).

In Nigeria, between 1965 and 1975 serious income disparity widened substantially (Malton, 1979; Aigbokhan, 1997 and
Ipinnaiye, 2001). This means that though the economy seemed to be performing strongly, the gap between the lower income households and the upper income households was growing, which was an indication that the rapid economic growth experienced had only resulted in further concentration of national income in the hands of few proportion of the population (Malton, 1979 and Clarke et al., 2003). The level of income inequality according to Aigbokhan (1999) had worsened after the Structural Adjustment Programme (SAP) of 1986. 
Using the National Living Standard Survey (NLSS) data, Oyekale et al., (2006) found out that the overall Gini-index for Nigeria was 0.580 . Sectorically, income inequality was seen to be higher in the rural areas when compared with the urban areas; and that employment income increases income inequality while agricultural income decreases it. Income inequality has been known to be closely related to poverty (Addison and Corina, 2001; Adams, 1999 and Aboyade, 1983). As a result, income inequality can be detrimental to economic growth and development of any country.

Although predicted poverty reduction scenarios vary greatly depending upon the rate and nature of poverty related policies, actual evidence suggests that the depth and severity of poverty is still at its worst in Nigeria (Okunmadewa, et al., 2005). This situation is very disturbing and worrisome given the huge human and material resources that have been devoted to poverty reduction by successive governments and yet no noticeable success has been achieved in this direction.

Furthermore, despite the commitments already shown by many countries including Nigeria and the global approach as enshrined in the Millennium Development Goals towards the achievement of the goal of reducing income inequality, efforts geared at achieving this have been greatly hindered by insufficient knowledge of how to design appropriate policies that would call for broad participation, the modality of their implementation procedures and measurement of the overall impact on the economy.

A high level of income inequality exists between Nigerian rural and urban area(Oyekale et al., 2006). There also exists variations in the level of income obtained by people in the rural areas is on the increase which could very much be linked to the growing dimension of poverty even among the rural households, as high level of income inequality produces and unfavourable environment for economic growth and development (Oluwatayo, 2008). This differential between rural and urban incomes, most times, accounts for the ruralurban migration.

The causes and implications of changes in inequality in many societies remain unclear (Sewanyana et al., 2004). The components that make up the acceptable standard of living can be represented as a composite whole by the real income expressed in currency values, in this case naira. Since, poverty can be linked to the income level of individuals of households and their standard of living is a measure of income obtained or received by them. It then becomes necessary to analyse income inequalities and welfare of farmers in Abia State, Nigeria, where the occupation of majority is farming.

Specifically, the objectives of the study are to: access the income inequality of the farmers; determine the factors that influence welfare among the farmers in the study area; and make recommendations based on the findings.

\section{MATERIALS AND METHODS}

\section{Study Area}

The study area is Abia State. Abia State is one of the 36 States in Nigeria. The State lies between Longitude $04^{\circ} 45^{\prime}$ and $06^{\circ} 07^{\prime}$ North and Latitude $07^{\circ} 00^{\prime}$ and $08^{\circ} 10^{\prime}$ East. It is situated in the South-East geo-political zone of Nigeria and is bounded by Imo State on the West, Ebonyi and Enugu States on the North, Cross Rivers and Akwa Ibom States on the East and Rivers State on the South. The State has a population density of 580 persons per square kilometer and a population of 2,833,999 persons (NPC, 2007). It has three senatorial zones namely Abia North, Abia South and Abia Central with seventeen Local 
Government Areas. Agriculturally, the State is divided into three agricultural zones also. They are Umuahia, Ohafia and Aba Zones.

The climate of the State is a tropical one and usually humid all year round; with two seasons, the rainy and the dry seasons. The rainy seasons starts from March to October while the dry season starts from November and ends February/March.

The major occupation of the people is farming and the major crops grown are Maize, yam, cassava, rice, vegetable, etc. Livestock kept include, goat, sheep. Pigs, etc. Plantain, palm oil, cocoa and rubber are some of the cash crops produced by the people.

Umuahia, Aba and Ohafia are the urban areas, while the rest are rural. Aba which is the commercial nerve centre of the State is home to many industrial outfits including agricultural processing firms.

\section{Selection of Respondents}

Multi-stage sampling technique was adopted for this study. First, two Local Government Areas were selected from each of the three agricultural zones. From these Local Government Areas, three communities were chosen. Finally, a random selection of twenty farmers was selected each from the three communities, bringing a total of one hundred and eighty (180) farmers/respondents.

\section{Method of Data Collection}

Primary source of data was used for the study. This was actualized with questionnaire administered to the already selected respondents. Enumerators who had already been trained assisted in the distribution and collection of data.

\section{Method of Date Analysis}

Objective (i) was realized using Ginicoefficient while objective (ii) was achieved using multiple regression.

Model Specification

The model for the Gini-coefficient is specified thus:

$$
\operatorname{Lgin}(y)=2 \sum_{\overline{\mathrm{i}=1} \mathrm{i} \mathrm{n}^{2} \mu}^{\mathrm{n}} \mathrm{i}\left[-\frac{\mathrm{n}+1}{2}\right] \mathrm{y}_{\mathrm{i}}
$$

Where: $\mathrm{n}=$ number of observation

$\mu=$ mean of the distribution

$y_{i}=$ income of the $j$ th household

Igini $=$ Income Gini

This model has been used in the past by Oluwatayo (2008).

The implicit function of the regression is given as:

$Q=f\left(X_{1} \ldots \ldots \ldots \ldots \ldots X_{n} e\right)$

$\mathrm{Q}=$ expenditure on food and non food

$\mathrm{X}_{\mathrm{i}} \ldots \ldots \ldots \mathrm{X}_{\mathrm{n}}=$ explanatory variables

$\mathrm{e}=$ error term

The four functional forms of the model, linear, Semi-log, double $\log$ and exponential were tried and the one that gave the best fit based on econometric considerations was chosen.

\section{RESULTS AND DISCUSSION}

\section{Assessment of the Income Inequality among the Respondents}

The Gini-coefficient has been used in the past to measure the level of inequalities in many other contexts besides income, including wealth, education, energy consumption, etc (Jacobson et al., 2007). However, this study was based on income inequalities. Inequality decomposition is a standard technique for examining the contributions of inequality of particular characteristics and can be used 
to assess income recipient characteristics and income package influences (Oyekale, et al., 2006). According to Babatunde (2008), inequality can be conceptualized as the dispersion of a distribution, whether one is considering income, consumption or some other welfare indicators.

In this study the Gini coefficient obtained using the formula as specified above was 0.67. This result means that there is a high income inequality in the study area. According to Dillon and Hardaker (1993); Gini coefficient higher than 0.35 indicates higher inequality. Poverty and income inequality are closely related and it has been argued that income inequality is a manifestation as well as strong cause of poverty (UNU/WIDER, 2000). Furthermore, Kolenikov and Shorrocks (2003) found that a high level of poverty in the late 1990s in Russia was due more to the rise in income inequality. Thus as income inequality increases, the incidence of poverty also increases. The result of the present study is in line with Adejare (1999) and World Bank (2003).

Table 01: Estimates of the Factors that Influence Farmers' Welfare in the Study Area.

\begin{tabular}{lllll}
\hline Variables & Linear & Semi-Log & Double Log & Exponential + \\
\hline \multirow{2}{*}{ Constant } & 28793.839 & -80310.492 & 9.110 & 10.052 \\
& $(2.235)^{* *}$ & $(-0.113)$ & $(2.749)^{* * *}$ & $(9.122)^{* * *}$ \\
Age & -2125.915 & -64108.609 & 0.068 & -0.005 \\
& $(-0.513)$ & $(-0.394)$ & $(0.089)$ & $(-0.250)$ \\
Marital Status & 184458.97 & 148229.06 & 0.812 & 1.164 \\
& $(2.553)^{* * *}$ & $(1.975)^{*}$ & $(2.317)^{* *}$ & $(3.087)$ \\
Farm Type & -144128.2 & -169595.2 & -0.969 & -0.208 \\
& $(-1.923)^{*}$ & $(-1.875)$ & $(-4.365)^{* * *}$ & $(-0.532)$ \\
Educational Attainment & 9141.056 & 122180.31 & 0.485 & 0.014 \\
& $(6.389)^{* * *}$ & $(1.133)$ & $(0.963)$ & $(0.293)$ \\
Farm Size & 20179.445 & 26854.498 & 0.644 & 0.134 \\
Access to Credit & $(1.932)^{*}$ & $(0.582)$ & $(2.995)^{* * *}$ & $(2.473)^{* *}$ \\
Income & 222107.51 & 2873.439 & -0.226 & -0.799 \\
Cost of Labour & $(3.150)^{* * *}$ & $(0.038)$ & $(-0.645)$ & $(-3.027)^{* * *}$ \\
& -0.024 & -4282.615 & -0.058 & 8.421 \\
Framing Experience & $(-0.526)$ & $(-0.192)$ & $(-0.553)$ & $(3.624)^{* * *}$ \\
Household Size & -0.086 & 25444.570 & 0.093 & -8.651 \\
R ${ }^{2}$ & $(-1.034)$ & $(0.981)$ & $(0.768)$ & $(-3.716)^{* * *}$ \\
F-ratio & 7517.484 & 94277.709 & 0.810 & 0.912 \\
\hline & $(1.547)$ & $(3.331)^{* * *}$ & $(3.584)^{* * *}$ & $(7.297)^{* * *}$ \\
& 9928.057 & -434701.2 & 0.427 & 0.155 \\
& $(0.664)$ & $(-5.178)^{* * *}$ & $(1.090)$ & $(2.003)^{*}$ \\
& 0.676 & 0.416 & 0.574 & 0.705 \\
& $5.834 * * *$ & $3.305 * * *$ & $2.273 * *$ & $6.541 . * * *$ \\
\hline
\end{tabular}

Source: Computations from Field Survey, 2011|

Note: Figures in parenthesis are the t-values; $* * *$ - denotes $1 \%$ significant level; $* *$ - denotes 5\% significant level; * - denotes $10 \%$ significant level; + - lead equation 


\section{Determinants or Factors Influencing Farmers Welfare}

In estimating the factors influencing farmer's welfare in the study area, four functional forms of regression model was tried, viz: linear, semi-log, double log and exponential. However, the exponential model was chosen as the lead equation based on some econometric considerations such as number of significant variables, the F-ratio, and the $\mathrm{R}^{2}$ value.(Table 01)

From the result in the Table 01, marital status, farm size, access to credit, value of access, cost of labour, farming experience and household size of the farmers were significant at various levels and signs.

The coefficient of married respondents was positive and significant at one percent level. This means that marriage tend to influence welfare of farmers positively. Oluwatayo (2008) had opined that expenditure increases with marriage, thus giving rise to a negative relationship in his study. The result of the present study seems plausible because of other livelihood activities embarked upon by couples outside farming which they also embark on together.

Farm size was also positive and significant at five percent risk level. The implication is that the larger the size of farm, the more their welfare status is improved. Given the fact that the larger the farm size, the greater the chances of increased farm income, the result is very plausible. This result is also in line with Oluwatayo (2008). The coefficient of access to credit was significant at one percent but had a negative sign. This means that there is a negative relationship between farmers' access to credit and their welfare. It could be that because of the relatively high interest rate attached to credits, farmers usually resort to paying these interests at the expense of their welfare at least in the short run.
The coefficient of farmers' income was positive and significant at one percent level. This means that as income increases, welfare of farmers also increases. This result is similar to previous studies like Avery and Kannicke (1991) and Ukoha et al., (2007).

The cost of labour was significant at one percent risk level but with a negative sign. This meant that as cost of labour increases, farmer's welfare decreases. Farming experience has a positive sign and significant at one percent level. This means that as farming experience increases as a result of the number of years spent in farming, welfare also increases. This result is consistent with Agwu (2009). The coefficient of household size which was represented by the number of persons in the household was also positive and significant at 10 percent level. This suggests that as household size increases, farmers welfare also increases. This result is in contrast with Ukoha et al., (2007). However, the possible reason could be that increased household size could be used for farm labour, thus reducing the cost of labour which is an additional expenditure and thus capable of reducing farmer's welfare.

The $\mathrm{R}^{2}$ value which is the coefficient of multiple determination was 0.705 , meaning that 70.5 percent of the variables were explained by the model. This is fairly high. The F-ratio was 6.541 and is significant at one percent level.

\section{CONCLUSION}

The study accessed income inequalities and welfare status among farmers in Abia State, Nigeria. The result has shown that there exist high income inequalities among the farmers in the study area.

The study recommends that efforts should be made to narrow down or close the gap of income disparities. Non-credit policies should be emphasized more. This is against 
the backdrop that having access to credit had a negative relationship with farmers' welfare. Efforts should also be made to increase farmers' income. To this end, government policies targeted at farmers should be strengthened. This will in no small way boast farmers' income and thus their welfare.

Cost of labour which had a negative correlation with welfare should be reduced. To this end, cost saving technologies should be introduced and farmer educated to adopt such measures.

It is also recommended that activities aimed at boasting farmers' income should be intensified. To this end, the much talked about access to roads, and markets should not only be talked about on commentaries and promises but should be practicalised. This will go a long way in boasting farmer's income.

\section{REFERENCES}

Aboyade, O. (1983). Integrated economics: a study of developing economies; Addison- Wesley Publishers Ltd.

Adams, R.H. (Jnr) (1999). Non-farm income, inequality and land in rural Egypt. PRMPO/ MNSED, unpublished report for comment, World Bank, Washington DC

Addison, T. and G.A. Cornia (2001). income distribution policies for faster poverty reduction. WIDER Discussion Paper No. 2001/93, World Institute for Development Economic Research.

Adejare, A.A. (1999). Impact of soyabean consumption of food sufficiency in Ibadan metropolis. M.Sc Thesis, Department of Agricultural Economics, University of Ibadan, Nigeria.

Agwu, N.M. (2009). Economics of processing maize into pap (akamu) and maize meal (agidi) in Enugu State, Nigeria. Journal of Sustainable Development, 6, volume 1, Pp. 47-53.

Aigbohkan, B.E. (1999). The impact of adjustment policies and income distribution in Nigeria: an empirical study. Research Report No. 5. Development Policy Centre, Ibadan, Nigeria.

Aigbokhan, M.S. (1997). poverty alleviation in Nigeria: some macroeconomic issues. NES annual conference proceedings. Pp. 181-209.

Atkinsion, A.B. and F. Bourguignon (2000). Introduction: income distribution and economics. In A.B. Atkinson and F. Bourguignon (eds). handbook of income distribution, Vol. 1, North Holland: Amsterdam.

Avery, E.B. and A.B. Kanniekel (1991). Household savings in the U.S. Review of Income and Wealth Series, 37.

Babatunde, R.O (2008). Income inequality in rural Nigeria: evidence from farming households survey data. Australian Journal of Basic and Applied Sciences, 2 volume 1, Pp. 134 -140 .

Clarke, G.L.; X. Colin and H. Zou (2003). Finance and inequality: test of alternative theories. World Bank Policy Research Working Paper 2984. Washington DC. World Bank 
Dillon, J.L and J.B. Hardaker (1993). Farm management research for small farmer development. Rome: FAO

Ipinnaiye, A.O. (2001). A decomposition analysis of the sources of income inequality in Ibadan metropolis. unpublished B.Sc Project, Department of Agricultural Economics, University of Ibadan.

Jacobson, A.; A.D. Milman and D.M. Kammen (2007). Letting the (energy) gini out of the bottle: Lorenz curves of cumulative electricity consumption and gini coefficients as metrice of energy distribution and equity. Energy Policy 33, Pp.1825 - 1832

Kolenikov, S. and A. Shorrocks (2003). A decomposition analysis of regional poverty in Russia. Discussion paper No. 2003/74. World Institute for Development Economic Research (UNU/WIDER), Helsinki.

Matlon, P. (1979). Income distribution among farmers in Northern Nigeria: empirical result and policy implications. African rural economy paper No. 18. East Lansing, Mich, USA: Michigan State University.

National Population Commission (2007). Results of the 2006 population census. National Population Commission, Abuja, Nigeria, 2007

Okunmadewa, F. Y.; S.A. Yusuf and B.T. Omonona (2005). social capital and poverty reduction in Nigeria. revised report submitted to Africa Economic Research Consortium (AERC) Nairobi, Kenya.

Oluwatayo, I.B. (2008). Explaining inequality and welfare status of households in rural Nigeria: evidence from Ekiti State. Humanity and Social Sciences Journal, 3, volume 1, Pp. 70-80.

Oyekale, A., Adeoti, A.I and T.O. Ogunnupe (2006). Measurement and sources of income inequality among rural and urban households in Nigeria, University of Ibadan. PMMA working paper No. 2006-20. Retrieved from http://papers.ssrn.com/so13/cf_dev/ absbyauth.cfm.

Sewanyana, N.S., A.J. Okidi; D. Angemi and V. Barungi (2004). Understanding the determinants of income inequality Uganda. CASE Working Papers, 2004-29.

Ukoha, O.O.; R.O. Mejeha and I.N. Nte (2007). Determinants of farmers welfare in Ebonyi State, Nigeria. Pakistan Journal of Social Science, 4, volume 3, Pp. 351-354.

UNU/WIDER (2000). United Nations University/ World Institute for Development Economic Research, World Inequality Database, Vol. 10, Helsinki.

World Bank (2003). Development indicators for 2002. Washington DC: World Bank. Pp. 74-75 